\title{
Can microhabitat selection or differences in 'catchability' explain male-biased sex ratios in overwintering populations of monarch butterflies?
}

\author{
DENNIS F. FREY \& KINGSTON L. H. LEONG \\ Biological Sciences Department, Cal Poly State University, San Luis Obispo, CA 93407, U.S.A.
}

Populations of butterfilies often have male-biased secondary sex ratios (Tabashnik 1980; Ehrlich 1989). Brussard \& Ehrlich (1970) proposed several hypotheses to account for this phenomenon including: (1) male-biased primary sex ratios, (2) differential mortality during pre-adult stages, (3) lags in emergence times of females resulting in sampling bias and (4) differences in 'catchability' due to sex-related differences in behaviour, also leading to sampling bias. An additional factor could be post-eclosion female-biased mortality. Monarch butterflies, Danaus plexippus, at their California overwintering sites have male-biased adult sex ratios (Urquhart 1960; Tuskes \& Brower 1978; and this study). From their western North American spring and summer breeding range, monarchs migrate to stands of predominantly eucalyptus and Monterey pine along the California coastline from the Mexican border north to Mendocino County, California (Tuskes \& Brower 1978; Nagano \& Lane 1985). Here we provide information that bears on these hypotheses.

We studied the behavioural ecology of overwintering monarchs at a site along the central coast of California from the butterflies' late September arrival until they dispersed in mid-March. This site is a 1.43-ha area of predominantly blue gum, Eucalyptus globulus, with scattered Monterey cypress, Cupressus macrocarpa, and Monterey pine, Pinus radiata, situated in North Beach campground, Pismo Beach, California $\left(35^{\circ} 07^{\prime} 46^{\prime \prime} \mathrm{N}\right.$, $120^{\circ} 37^{\prime} 53^{\prime \prime} \mathrm{W}$ ). It is $0.5 \mathrm{~km}$ from the Pacific Ocean and the nearest overwintering site lies $2.0 \mathrm{~km}$ to the south.

On a typical site visit during the 1990-1991 overwintering season, $16 \cdot 7 \pm 1 \cdot 8(\bar{X} \pm \mathrm{SE}, N=21$ visits $)$ trees had clusters of butterflies present and $8.0 \pm 1 \cdot 0$ trees had over 1000 individuals on them. Some trees had in excess of 20000 individuals at various times. The majority of clusters formed on south-facing portions of the trees and extremes of roosting position were $7.9 \pm 0.2 \mathrm{~m}(N=91)$ for the lowest clusters and $15.4 \pm 0.5 \mathrm{~m}(N=91)$ for the highest clusters. The maximum recorded height during the season was $24.5 \mathrm{~m}$. The tree-use pattern was similar to that described by Frey et al. (1992) for other sites within San Luis Obispo County.

Male monarchs with wings in a spread or open position are distinguished from females by a patch of black scales covering the scent gland on the hind wings. To enable us to identify males from females when their wings were folded over their dorsum (typical of their clustering or roosting posture), we marked 6006 butterflies between 1 November 1990 and 11 January 1991. We made small marks with 'Sharpie' permanent markers (red: male, green: female) in the discal cell of the underside of the hind wings. We could easily distinguish marked males from marked females at roosting height using binoculars.

For monarch mark-release-recapture studies at overwintering sites, long-handled nets (to $10-\mathrm{m}$ reach) are usually used to capture clustering individuals from the lower sections of cluster-trees. This often means that over $70 \%$ of the population is not available for sampling. If males tended to roost lower on a tree than females, this could account for male bias in sex ratios. To test for sex differences in microhabitat selection by our marked individuals, we studied their settling pattern on 10 different occasions from 19 January to 25 February 1991 between 0800 and 0930 hours PST. The dispersion of males and females was recorded from nine different trees situated in the northeast portion of the site. At this time of the season about $4 \%$ of the trees previously used for clustering are abandoned each 
Table I. Distribution of monarchs by microhabitat and sex

\begin{tabular}{lcc}
\hline $\begin{array}{l}\text { Position } \\
\text { on tree }\end{array}$ & Males & Females \\
\hline Upper third & 85 & 46 \\
Lower third & 97 & 50 \\
\hline
\end{tabular}

$\chi^{2}=0 \cdot 04, d f=1, P=0 \cdot 814$.

day for new cluster-trees. This 'turnover' resulted in one of the trees being searched by us only once, while another was observed eight times. The median interval between consecutive scan dates of the same tree was 4 days. Weather for January and February was uniformly warmer and drier than the 30-year average (U.S.N.O.A.A. 1991) and maximum daily temperatures during the study exceeded flight thresholds each day, i.e. $13^{\circ} \mathrm{C}$ (Masters et al. 1988), which promoted intra-site movement between sampling dates.

For a tree to be included in our sampling effort: (1) there had to be at least 1000 monarchs present, (2) the lower third of the clusters had to be within reach of our net, while (3) the upper third would have been beyond our reach had we been collecting. Depending on the density of butterfies on a tree and the number of clusters present, we spent from 10 to 20 min scanning each tree with binoculars. We systematically scanned the upper third of the vertical dispersion and the lower third of the distribution and recorded the frequency of marked males and females present.

The distribution of butterflies by sex and roosting location for 28 'tree-days' is given in Table $I$. The estimated sex ratio from our November markrelease-recapture sessions was 60:40 (male:female) and 58:42 from the early January census. These values were similar to those we found at Natural Bridges State Park, Santa Cruz, California over the same period of time. We spotted 182 marked males $(65.5 \%)$ and 96 marked females (34.5\%). Choice of roosting location (i.e. clustering height) was independent of $\operatorname{sex}\left(\chi^{2}=0.04, d f=1, P=0.814\right)$. This suggests that selection of clustering microhabitat is similar between male and female monarchs and does not constitute a strong hypothesis regarding male-biased sex ratios.

Tabashnik's (1980) test of equal catchability between the sexes was also applied to the November-January mark-release-recapture data.
For this census work we had taken butterflies clustering in the lower sections of cluster-trees with a long-handled net. This test compares the capture sex ratio based on recaptured marked individuals with the estimated sex ratio of capture totals, where the sex ratio is given as a decimal fraction of males/ females. The overall capture sex ratio $(1.42)$ was not significantly different from the estimated sex ratio (1.4J) indicating no difference in catchability between the sexes (Mann-Whitney $U$-test: $N=7$, $P=0.749$ ).

Sex ratios of 1:1 have been reported for monarchs at emergence by Urquhart (1960) for eastern.U.S.A. populations and by Eric Johnson (personal communication) and Walt Sakai (personal communication) for California populations. This means that hypotheses (1) and (2) above are not applicable to this species. Since our sampling was done during the middle of the overwintering season, hypothesis (3) is also not relevant. Zalucki \& Kitching (1982) found a number of sex-related differences in the movement of non-overwintering phase monarchs, including less movement in the vertical plane by males and a tendency for them to move faster than females. It is not known whether similar differences occur during periods of flight at overwintering sites. However, given the results of this study and the fact that sex ratios are equal at emergence, but malebiased sex ratios are found throughout the overwintering season, the most probable explanation for this phenomenon seems to be female-biased mortality along the summer and autumn migration routes to overwintering sites in California.

We thank the California State Parks and Recreation Department for their support during this study and two anonymous referees for their comments.

\section{REFERENCES}

Brussard, P. \& Ehrlich, R. 1970. The population structure of Erebia epipsodea (Lepidoptera: Satyrinae). Ecology, 51, 119-129.

Ehrlich, P. 1989. The structure and dynamics of butterfly populations. In: The Biology of Butterfies (Ed. by R. Vane-Wright \& P. Ackery), pp. 25-40. Princeton: Princeton University Press.

Frey, D., Leong, K. L. H., Fredericks, D. \& Raskowitz, S. 1992. Clustering patterns of monarch butterflies (Danaidae: Lepidoptera) at two California central coast overwintering sites. A. Entomol. Soc., 85, 148-153.

Masters, A., Malcolm, S. \& Brower, L. 1988. Monarch butterfly (Danaus plexippus) thermoregulatory behavior and adaptations for overwintering in Mexico. Ecology, 69, 458-467. 
Nagano, C. \& Lane, J. 1985. A survey of the location of Monarch butterfly (Danaus plexippus (L.)) overwintering colonies in the state of California, U.S.A. first year 1984/1985. Report to the World Wildlife Fund-U.S. Monarch Project, Portland, Oregon.

Tabashnik, B. 1980. Population structure of Pierid butterflies. Oecologia (Berl.), 47, 175-183.

Tuskes, P. \& Brower, L. 1978. Overwintering ecology of the monarch butterfly, Danaus plexippus L., in California. Ecol. Entomol., 3, 141-153.
Urquhart, F. 1960. The Monarch Butterfy. Toronto: University of Toronto Press.

U.S. National Oceanic and Atmospheric Administration (1991) Climatological Data. California 94.

Zaluchki, M. \& Kitching, R. I982. The analysis and description of movement in adult Danaus plexippus $\mathrm{L}$. (Lepidoptera: Danainae). Behaviour, 80, 174-198. 